\title{
Chemometric properties of wines treated with natural extracts as an alternative of sulphur dioxide
}

\author{
B. Darıcı and H.K. Yıldırım \\ Ege University, Department of Food Engineering, 35100 Bornova, Izmir, Turkey
}

\begin{abstract}
Sulphur dioxide $\left(\mathrm{SO}_{2}\right)$ is commonly used as an antioxidant and antimicrobial compound during wine production. Phenols naturally existence in plant extracts have been reported to possess antioxidative, antimicrobial activities, and as anti-inflammatory activities. Since few consumers preferred foods treated with natural preservatives, the aim of this study was to determine the effects of different natural plant extracts as an alternative of sulphur dioxide used in wines. Wine production was done according to the accepted conventional method for red wines (Cabernet sauvignon). The experimental design was achieved by using different plant extracts (grape pomace, rosemary, black blueberry) at different concentrations. As controls were used wine samples produced without natural extracts and second group samples produced without addition of sulphur dioxide $\left(\mathrm{SO}_{2}\right)$. At the end of production basic analyzes (total acidity, volatile acidity, $\mathrm{pH}$, dry matter, ash, free and total $\mathrm{SO}_{2}$ ), and colorimetric wine analyses (TWP, WC, $\mathrm{CD}, \mathrm{CI}, \% \mathrm{R}, \% \mathrm{Y}, \% \mathrm{~B}$, Abs280, Abs420, Abs520, Abs620, \%dA and tint values) were performed. Analyses on n-dimensional scale demonstrated that each used plant exact have different effects on required $\mathrm{SO}_{2}$ and wine quality parameters. The lowest concentrations of grape pomace extract caused reduction of $\mathrm{SO}_{2}$ and maintaining the required wine properties. The highest value of the end of first month of storage for TWP, WC, Abs280, Abs520, \%R values were determined for grape pomace treatment wines. The highest value of the TPW were determined for samples treated with grape pomace $(1 \mathrm{ml} / \mathrm{L}$ extract), rosemary $(1 \mathrm{ml} / \mathrm{L}$ extract $)$, and blue berry $(1 \mathrm{ml} / \mathrm{L}$ extract with $25 \mathrm{mg} / \mathrm{L} \mathrm{SO}_{2}$ ) 2.710, 2.550 and 2.520 respectively. Results emphasized the importance of used plant extracts and their concentrations. The study demonstrated the possibilities of $\mathrm{SO}_{2}$ optimization on the base of used natural plant extracts.
\end{abstract}

\section{Introduction}

During wine production, $\mathrm{SO}_{2}$ is used as an antioxidant and antimicrobial additive for preventing oxidation and the spread of unwanted organisms (wild yeast, acetic acid bacteria, lactic acid bacteria) [1]. During wine aging, there is a gradual loss of phenolic compounds due to their participation in a number of chemical reactions such as oxidation (with polysaccharides and tannins) and formation of other stable anthocyanin-derived pigments. Used $\mathrm{SO}_{2}$ could compensate partially the phenolic compounds effects on wines. All these reactions resulted in marked required changes in the colour, mouth feel and flavour properties of red wines [2]. Even these advantages, some negative effects of $\mathrm{SO}_{2}$ on human health have been subject to researches for many years [3]. The daily intake of sulphite was assumed to be $43 \mathrm{mg} / \mathrm{g}$ on average for an individual weighing $60 \mathrm{~kg}$ [4]. The quantity $\mathrm{SO}_{2}$ was gradually reduced due to some health precautions [5]. Recently, uses of natural preservatives, as an alternative of $\mathrm{SO}_{2}$ have been tested. Some of them included non-thermal processes and some of them proposed using of new chemicals. The most promising natural alternatives of sulphides in wine production are using of natural plant extracts [6]. Phenolic compounds and their derivatives, which are found in the structure of these extracts, have been shown to be effective in preventing auto oxidation [7-9]. It was stated that other phytochemicals (terpenes, alkaloids, lactones, etc.) found in the extract may also contribute to the antioxidative properties of these extracts. Then a rises the question, what are the effects of these compounds on wine chemometric properties. The aims of this study were to determine the effects of different natural plant extracts (grape pomace, blueberry and rosemary) used as an alternative of sulphur dioxide on wine chemometric properties of wines.

\section{Material and methods}

\subsection{Plant material}

As materials were used grapes of Vitis vinifera L. cv. origin var: Cabernet sauvignon from the Menderes/Gölcükler region of Izmir. $100 \mathrm{~kg}$ grapes were processed in Ege University Food Engineering Department (Izmir/Turkey) within $24 \mathrm{~h}$ of hand-harvest.

The grape pomace (GP) extract was supplied as waste from the wine production process of Cabernet sauvignon grapes. The blueberry $(\mathrm{Bb})$ and rosemary $(\mathrm{R})$ extract used in the experimental plan were with Rosmarinus officinalis L. and Vaccinium myrtillus L. spices origin, respectively. These plants were obtained from the same region of Turkey (Izmir). 


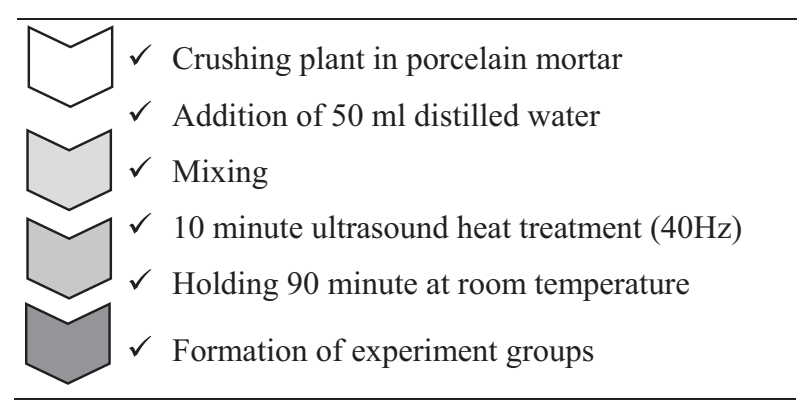

Figure 1. Natural extracts preparation.

\subsection{Wine processing}

The grapes were transferred to the mill for separation of stems, wastes and foreign materials after weighing process. Crushed fruits were collected in stainless steel tank. The density of the must was determined as $1110 \mathrm{~g} / \mathrm{cm}^{3}$, if the average $\mathrm{pH}$ as 3.8 and the total acid amonth as $5.48 \mathrm{~g} / \mathrm{L}$ (tartaric acid). As culture was used Saccharomyces cerevisiae (20 g/L dose SIHA Active Dry yeast 10). The must was stirred twice daily. The alcoholic fermentation was carried out in controlled conditions. The fermentation process was completed in 12 days at $20-22{ }^{\circ} \mathrm{C}$. The pressing operation was done by a mechanical press machine. During alcoholic fermentation, the density and temperature measurements were carried out. Using these data the alcohol and sugar content were determined. At the end of the fermentation, the final sugar content was determined as $<1 \mathrm{~g} / \mathrm{L}$. At the end of alcoholic fermentation sterilization procedure were carried out. Obtained wines were stored at $15^{\circ} \mathrm{C}$. With the addition of the extracts, the samples were bottled and stored for 3 months.

\subsection{Experimental design and treatments}

Natural extracts were prepared as following the path given in Fig. 1.

The experimental design was achieved by using different plant extracts (grape pomace, rosemary, black blueberry) at different concentrations. As controls were used wine samples produced without added natural extracts and second group samples produced without addition of sulphur dioxide $\left(\mathrm{SO}_{2}\right)$. Extracts were added to the wine samples after fermentation. The experimental groups are demonstrated in Table 1.

\subsection{Analyses}

Wine samples were collected after 1,2 and 3 month of storage during aging in bottles at $15 \pm 2{ }^{\circ} \mathrm{C}$. Basic must and wine analyzes were carried out according to the OIV Compendium of International Methods of wine and must [10]. All analyzes were carried out in duplicate.

\subsubsection{Basic wine analyzes}

Basic oenological wine analyzes were determined according to recommended methods by International Organization Vine and Wine (OIV) [11]. Alcohol content (\% v/v), $\mathrm{pH}$, (direct measurement by using $\mathrm{pH}$ meter), total acidity (tartaric acid $\mathrm{g} / \mathrm{L})$, volatile acidity amonth $(\mathrm{g} / \mathrm{L}$ acetic acid), total and free $\mathrm{SO}_{2}(\mathrm{mg} / \mathrm{L})$, dry matter $(\mathrm{g} / \mathrm{L})$ and ash $(\mathrm{g} / \mathrm{L})$ analyzes were performed.
Table 1. Experimental Groups.

\begin{tabular}{|c|c|c|c|}
\hline \multirow{2}{*}{ Group } & \multicolumn{3}{|c|}{ Treatments with wine samples } \\
\cline { 2 - 4 } & $\begin{array}{c}\mathrm{SO}_{2} \text { addition } \\
\mathrm{mg} / \mathrm{L}\end{array}$ & $\begin{array}{c}\text { Extract addition } \\
\mathrm{ml} / \mathrm{L}\end{array}$ & $\begin{array}{c}\text { Sample } \\
\text { codes }\end{array}$ \\
\hline \multirow{3}{*}{ Grape Pomace (Gp) } & 0 & 1 & GP01 \\
\cline { 2 - 4 } & 25 & 0.7 & $\mathrm{GP} 257$ \\
\cline { 2 - 4 } & 25 & 0.3 & $\mathrm{GP} 253$ \\
\cline { 2 - 4 } & 25 & 1 & $\mathrm{GP} 251$ \\
\hline \multirow{3}{*}{ Rosemary (R) } & 0 & 1 & $\mathrm{R} 01$ \\
\cline { 2 - 4 } & 25 & 0.7 & $\mathrm{R} 257$ \\
\cline { 2 - 4 } & 25 & 0.3 & $\mathrm{R} 253$ \\
\hline \multirow{3}{*}{ Blueberry (Bb) } & 25 & 1 & $\mathrm{R} 251$ \\
\cline { 2 - 4 } & 25 & 1 & $\mathrm{Bb} 01$ \\
\cline { 2 - 4 } & 25 & 0.7 & $\mathrm{Bb} 257$ \\
\cline { 2 - 4 } & 25 & 1 & $\mathrm{Bb} 251$ \\
\hline Control 1 & 0 & 0 & $\mathrm{TK} 00$ \\
\hline Control 2 & 25 & 0 & $\mathrm{TK} 25$ \\
\hline
\end{tabular}

\subsubsection{Chromatic measurements}

The absorbance measurements of wine samples were determined by spectrophotometric method (Pharmacia LKB, Novaspec II). Measurements were determined by using $1 \mathrm{~mm} 1-\mathrm{mm}$ cell path. Absorbance was determined at 280, 420, 520 and $620 \mathrm{~nm}$ wavelengths. Required dilutive were done prior analyses [15]. Special wine chromatic parameters were determined by following equations (Equations from 1 to 7):

colour density (CD),

$$
C D=A b s 420 n m+A b s 520 n m
$$

color intensity (CI),

$$
C I=A b s 420 n m+A b s 520 n m+A b s 620 n m
$$

tint value,

$$
T=A b s 420 / A b s 520
$$

proportion of red colour produced by flavylium cations (\% dA),

$$
\begin{aligned}
\% d A= & ([A b s 520-(A b s 420-A b s 620) / 2]) / \\
& A b s 520^{*} 100
\end{aligned}
$$

proportion of red colour (\%R),

$$
\% R=A b s 520 / C I^{*} 100
$$

proportion of yellow colour $(\% \mathrm{Y})$,

$$
\% Y=A b s 420 / C I^{*} 100
$$

proportion of blue colour $(\% \mathrm{~B})$,

$$
\% B=A b s 620 / C I^{*} 100
$$

For total wine pigment (TWP) analysis, $9 \mathrm{ml}$ of $0.1 \mathrm{~N}$ $\mathrm{HCl}$ was added to $1 \mathrm{ml}$ of wine samples diluted 10 times with distilled water. After $\mathrm{pH}<1.0$ was obtained, sample 
Table 2. Basic wine analyzes results.

\begin{tabular}{|c|c|c|c|c|c|c|c|c|c|c|c|c|c|c|c|}
\hline \multirow[t]{2}{*}{ Analyzes \& Storage } & \multicolumn{15}{|c|}{ Experimental Groups* } \\
\hline & & TK00 & TK25 & GP01 & GP257 & GP253 & GP251 & R01 & R257 & R253 & R251 & Bb01 & Bb257 & Bb253 & Bb251 \\
\hline \multirow{3}{*}{ pH } & 1 & 3.79 & 3.75 & 3.75 & 3.75 & 3.78 & 3.78 & 3.79 & 3.90 & 3.90 & 3.78 & 3.78 & 3.79 & 3.78 & 3.79 \\
\hline & 2 & 3.70 & 3.73 & 3.96 & 3.95 & 3.98 & 3.95 & 3.73 & 3.72 & 3.82 & 3.75 & 3.80 & 3.86 & 3.83 & 3.92 \\
\hline & 3 & 3.92 & 3.94 & 3.92 & 3.93 & 3.92 & 3.92 & 4.06 & 4.03 & 4.03 & 4.02 & 4.90 & 3.91 & 3.90 & 3.91 \\
\hline \multirow{3}{*}{ Total acidity (g/L) } & 1 & 5.40 & 5.90 & 5.10 & 5.30 & 5.00 & 5.50 & 5.00 & 4.70 & 4.50 & 5.70 & 5.60 & 5.10 & 5.30 & 4.90 \\
\hline & 2 & 4.90 & 5.50 & 5.60 & 5.30 & 6.70 & 5.00 & 4.70 & 4.70 & 4.80 & 4.80 & 4.80 & 4.70 & 4.80 & 4.90 \\
\hline & 3 & 4.90 & 5.30 & 5.20 & 5.20 & 5.40 & 4.90 & 4.60 & 4.60 & 4.70 & 4.60 & 4.70 & 3.90 & 4.70 & 4.70 \\
\hline \multirow{3}{*}{ Free $\mathrm{SO}_{2}(\mathrm{mg} / \mathrm{L})$} & 1 & 2.20 & 7.50 & 2.50 & 5.40 & 6.00 & 5.20 & 2.30 & 4.90 & 5.30 & 4.80 & 2.40 & 6.20 & 6.10 & 6.00 \\
\hline & 2 & 1.60 & 5.30 & 2.00 & 3.00 & 4.40 & 4.00 & 1.50 & 3.50 & 4.50 & 4.10 & 2.20 & 4.70 & 4.70 & 4.90 \\
\hline & 3 & 1.40 & 5.00 & 1.50 & 2.60 & 3.00 & 3.10 & 1.40 & 2.20 & 2.80 & 2.30 & 1.50 & 2.80 & 2.60 & 3.10 \\
\hline \multirow{3}{*}{ Total $\mathrm{SO}_{2} \mathrm{mg} / \mathrm{L}$ ) } & 1 & 5.50 & 32.0 & 6.50 & 33.00 & 30.00 & 31.00 & 6.50 & 34.00 & 33.00 & 30.00 & 6.50 & 31.00 & 33.00 & 32.00 \\
\hline & 2 & 5.00 & 16.0 & 5.00 & 19.00 & 18.00 & 19.00 & 5.00 & 17.00 & 17.00 & 16.00 & 5.00 & 19.00 & 17.00 & 18.00 \\
\hline & 3 & 4.50 & 10.0 & 4.40 & 9.00 & 10.00 & 10.50 & 4.20 & 8.00 & 9.00 & 11.00 & 4.50 & 9.00 & 8.00 & 10.00 \\
\hline \multirow{3}{*}{ Volatile acidity (g/L) } & 1 & 0.68 & 0.24 & 0.50 & 0.41 & 0.45 & 0.34 & 0.51 & 0.36 & 0.39 & 0.30 & 0.69 & 0.48 & 0.50 & 0.40 \\
\hline & 2 & 0.72 & 0.45 & 0.69 & 0.44 & 0.49 & 0.40 & 0.55 & 0.40 & 0.48 & 0.36 & 0.71 & 0.45 & 0.60 & 0.42 \\
\hline & 3 & 0.84 & 0.69 & 0.72 & 0.56 & 0.59 & 0.52 & 0.67 & 0.54 & 0.60 & 0.50 & 0.74 & 0.59 & 0.71 & 0.57 \\
\hline \multirow{3}{*}{ Dry matter (g/L) } & 1 & 28.1 & 27.2 & 27.90 & 26.60 & 27.20 & 27.40 & 26.10 & 26.60 & 26.30 & 26.60 & 27.30 & 27.30 & 25.80 & 26.30 \\
\hline & 2 & 28.0 & 27.20 & 27.50 & 26.40 & 27.20 & 27.20 & 26.00 & 26.60 & 26.30 & 26.50 & 27.10 & 27.20 & 25.50 & 26.30 \\
\hline & 3 & 28.1 & 27.00 & 27.80 & 26.60 & 27.00 & 27.20 & 26.20 & 26.20 & 26.10 & 26.50 & 27.20 & 27.30 & 25.50 & 26.20 \\
\hline \multirow{3}{*}{$\operatorname{Ash}(g / L)$} & 1 & 4.00 & 4.00 & 4.50 & 4.50 & 4.50 & 4.50 & 4.00 & 4.00 & 4.00 & 4.00 & 4.50 & 4.50 & 4.50 & 4.50 \\
\hline & 2 & 4.00 & 4.00 & 4.50 & 4.50 & 4.00 & 4.50 & 4.00 & 4.00 & 4.00 & 4.00 & 4.00 & 4.50 & 4.00 & 4.00 \\
\hline & 3 & 3.50 & 4.00 & 4.50 & 4.50 & 4.00 & 4.50 & 3.50 & 3.50 & 4.00 & 4.00 & 4.00 & 4.00 & 4.00 & 4.00 \\
\hline
\end{tabular}

*TK00: without $\mathrm{SO}_{2}$ sample, TK25: $25 \mathrm{mg} / \mathrm{L} \mathrm{SO}$ added sample, GP01: $1 \mathrm{ml} / \mathrm{L}$ grape pomace extract, GP257: $25 \mathrm{mg} / \mathrm{L} \mathrm{SO} 2$ with 0,7 ml/L extract, GP253: $25 \mathrm{mg} / \mathrm{L}$ $\mathrm{SO}_{2}$ with $0,3 \mathrm{ml} / \mathrm{L}$ extract, GP251: $25 \mathrm{mg} / \mathrm{L} \mathrm{SO} \mathrm{S}_{2}$ with $1 \mathrm{ml} / \mathrm{L}$ extract, $\mathbf{R 0 1}: 1 \mathrm{ml} / \mathrm{L}$ rosemary extract, $\mathbf{R 2 5 7}: 25 \mathrm{mg} / \mathrm{L} \mathrm{SO} \mathrm{SO}_{2}$ with $0,7 \mathrm{ml} / \mathrm{L}$ rosemary extract, $\mathbf{R 2 5 3 :} 25 \mathrm{mg} / \mathrm{L}$ $\mathrm{SO}_{2}$ with $0,3 \mathrm{ml} / \mathrm{L}$ rosemary extract, $\mathbf{R 2 5 1}: 25 \mathrm{mg} / \mathrm{L} \mathrm{SO} \mathrm{SO}_{2}$ with $1 \mathrm{ml} / \mathrm{L}$ rosemary extract, $\mathbf{B b 0 1 :} 1 \mathrm{ml} / \mathrm{L}$ blueberry extract, $\mathbf{B b}_{257:} 25 \mathrm{mg} / \mathrm{L} \mathrm{SO} \mathrm{SO}_{2}$ with $0,7 \mathrm{ml} / \mathrm{L}$ blueberry extract, Bb253: $25 \mathrm{mg} / \mathrm{L} \mathrm{SO}_{2}$ with 0,3 ml/L blueberry extract, Bb251: $25 \mathrm{mg} / \mathrm{L} \mathrm{SO}_{2}$ with $1 \mathrm{ml} / \mathrm{L}$ blueberry extract.

was allowed to stand for 4.5 hours. Then absorbance was measured at $520 \mathrm{~nm}$. Distilled water was used as blank [13]. Wine colour (WC) analysis carried out with these steps; $2 \mathrm{ml}$ of the 5-fold diluted wine samples were taken with distilled water and $20 \mu$ l acetaldehyde (Merck) was added. After waiting 45 minutes, absorbance was measured at $520 \mathrm{~nm}$ [13]. HunterLab (coloflex, USA) device was used to determine the colorimetric values of wine samples. CIELab parameters L* (lightness), a* (redness), b* (yellowness) measurements were registered and distilled water as reference [16]. The croma values $\left(\mathrm{C}^{*}\right)$ and hue angle $\left(\mathrm{H}^{*}\right)$ of the samples were calculated by using the following formulas; $\mathrm{C} *=\left[\mathrm{a}^{2}+\mathrm{b}^{2}\right]^{1 / 2}, \mathrm{H} *=$ $(\arctan [\mathrm{b} / \mathrm{a}])$.

\subsection{Statistical evaluation}

Significant differences between averages were obtained at a 95\% significance level. The values were averaged and standard deviation, minimum, maximum and mean values of samples were determined.

\section{Results and discussion}

Statistically, the effect of different concentrations in the same experimental group was not significant but the effect of these groups was found to be significant $(p<0.05)$. The results of the main basic wine analysis results are given in Table 2.
Positive correlations of volatile acidity were found with Abs420 $(r=0.3432, p=0.026), \% \mathrm{Y}(r=0.4054$, $p=0.008)$, and tint $(r=0.4390, p=0.004)$. Similar correlations were found between total acidity and colour parameters such as; wine colour $(r=0.40, p=$ $0.009)$, Abs520 $(r=0.3918, p=0.01), \mathrm{CD}(r=0.3253$, $p=0.036), \quad \mathrm{R} \% \quad(r=0.4190, p=0.006) \quad$ and $\quad \mathrm{dA} \%$ $(r=0.3204, p=0.039)$.

\subsection{Colorimetric wine analyses}

Colour is one of the most important quality parameters of wine and one of the most important factors affecting the total acceptability of consumers $[17,18]$. It is known that $99.5 \%$ of the wine components are colourless in the visible light spectrum. The colours of red or white wines are known to be due to phenolic compounds found in small percentages [19]. The colour formation in wine takes place in a long period starting from fermentation to the end of storage [20-22]. It was reported that wines treated with phenolic compounds (such as tannin) prevent oxidation and cause sensory perception better than $\mathrm{SO}_{2}$ in wine to replace $\mathrm{SO}_{2}$ [23]. However, Bautista-ortan et al., 2005 found that two different tannins have no effect on the colour and other sensory properties of red wine [24]. Chromatic parameters were analyzed at bottling and after 3 months of storage in bottle of wines. The highest value in the first month of storage for TWP, WC, Abs280, Abs520, $\% \mathrm{R}$ values were determined for grape pomace treatment 
Table 3. Evaluation of colorimetric values of wines.

\begin{tabular}{|c|c|c|c|c|c|c|c|c|c|c|c|c|c|c|c|}
\hline \multirow{2}{*}{$\begin{array}{c}\text { Analyzes \& } \\
\text { Storage }\end{array}$} & \multicolumn{15}{|c|}{ Experimental Groups* } \\
\hline & & TKO0 & K25 & GP01 & GP257 & GP253 & GP251 & R01 & R257 & $\mathbf{R} 253$ & $\mathbf{R} 251$ & Bb01 & Bb257 & Bb253 & Bb251 \\
\hline \multirow{3}{*}{ TWP } & 1 & 0.02 & 06 & 71 & 63 & 1.55 & 1.13 & .55 & 01 & 86 & 0.82 & 2.10 & 1.63 & 1.28 & 2.52 \\
\hline & 2 & 0.77 & 1.03 & 1.71 & 1.62 & 1.53 & 1.74 & 0.79 & 0.82 & 0.84 & 0.81 & 1.21 & 1.52 & 1.24 & 1.53 \\
\hline & 3 & 0.72 & 1.03 & 1.50 & 1.59 & 1.51 & 1.72 & 0.72 & 0.77 & 0.75 & 0.71 & 1.01 & 1.31 & 1.31 & 1.51 \\
\hline \multirow{3}{*}{ WC } & 1 & 4.40 & 4.60 & 5.50 & 85 & 4.75 & 5.25 & 5.45 & 4.60 & 4.55 & 4.65 & 5.10 & 4.95 & 4.75 & 5.40 \\
\hline & 2 & 3.60 & 4.00 & 5.00 & 0 & 0 & 4.50 & 3.75 & 3.95 & 3.85 & 3.80 & 4.10 & 5 & 5 & 4.35 \\
\hline & 3 & 3.20 & 3.75 & 4.00 & 4.15 & 4.10 & 4.25 & 3.15 & 3.65 & 3.60 & 3.55 & 3.70 & 3.85 & 3.80 & 3.95 \\
\hline \multirow{3}{*}{ Abs 280} & 1 & 55.40 & .70 & 75.20 & 68.30 & 59.60 & 73.50 & 76.40 & 72.10 & 70.60 & 79.70 & 71.10 & 64.40 & 58.70 & 70.60 \\
\hline & 2 & 55.10 & 57.50 & 70.30 & 68.10 & 58.30 & 72.60 & 57.40 & 57.20 & 57.00 & 57.50 & 58.00 & 64.00 & 58.20 & 70.40 \\
\hline & 3 & 54.94 & 57.41 & 67.87 & 68.00 & 58.00 & 72.45 & 54.77 & 56.65 & 56.67 & 54.81 & 57.38 & 57.65 & 57.62 & 70.38 \\
\hline \multirow{3}{*}{ Abs 420} & 1 & 3.80 & 3.38 & 3.07 & 3.25 & 3.28 & 3.12 & 3.02 & 3.21 & 3.30 & 2.99 & 3.17 & 3.25 & 3.31 & 3.15 \\
\hline & 2 & 4.00 & 3.45 & 3.30 & 3.33 & 3.37 & 3.30 & 3.47 & 3.93 & 3.96 & 3.90 & 3.46 & 3.41 & 3.41 & 3.33 \\
\hline & 3 & 4.03 & 3.48 & 3.45 & 3.38 & 3.39 & 3.33 & 3.48 & 4.04 & 4.12 & 3.96 & 3.52 & 3.46 & 3.49 & 3.46 \\
\hline \multirow{3}{*}{ Abs520 } & 1 & 6.88 & 7.45 & 7.98 & 7.64 & 7.57 & 7.82 & 7.85 & 7.42 & 7.40 & 7.43 & 7.72 & 7.70 & 7.53 & 7.80 \\
\hline & 2 & 6.14 & 6.76 & 7.02 & 6.95 & 6.87 & 7.00 & 6.21 & 6.44 & 6.31 & 6.22 & 6.86 & 6.93 & 6.87 & 6.96 \\
\hline & 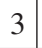 & 6.11 & 6.30 & 6.51 & 6.86 & 6.51 & 6.87 & 6.07 & 6.13 & 6.14 & 6.10 & 6.27 & 6.32 & 6.30 & 6.75 \\
\hline \multirow{3}{*}{ Abs620 } & t & 1.53 & 1.60 & 2.53 & 1.89 & 1.88 & 2.37 & 1.73 & 1.55 & 1.57 & 1.61 & 2.70 & 2.41 & 2.32 & 2.64 \\
\hline & 2 & 1.30 & 1.44 & 1.68 & 1.74 & 1.70 & 2.19 & 1.30 & 1.36 & 1.39 & 1.35 & 2.19 & 1.78 & 1.73 & 2.15 \\
\hline & 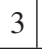 & 1.22 & 1.44 & 1.43 & 1.72 & 1.66 & 2.11 & 1.20 & 1.33 & 1.37 & 1.31 & 1.65 & 1.72 & 1.62 & 2.12 \\
\hline
\end{tabular}

*TK00: without $\mathrm{SO}_{2}$ sample, TK25: $25 \mathrm{mg} / \mathrm{L} \mathrm{SO}_{2}$ added sample, GP01: $1 \mathrm{ml} / \mathrm{L}$ grape pomace extract, GP257: $25 \mathrm{mg} / \mathrm{L} \mathrm{SO} 2$ with 0,7 ml/L extract, GP253: $25 \mathrm{mg} / \mathrm{L} \mathrm{SO}_{2}$ with $0,3 \mathrm{ml} / \mathrm{L}$ extract, GP251: $25 \mathrm{mg} / \mathrm{L} \mathrm{SO}_{2}$ with $1 \mathrm{ml} / \mathrm{L}$ extract, $\mathbf{R 0 1}: 1 \mathrm{ml} / \mathrm{L}$ rosemary extract, $\mathbf{R 2 5 7}: 25 \mathrm{mg} / \mathrm{L} \mathrm{SO}_{2}$ with $0,7 \mathrm{ml} / \mathrm{L}$ rosemary extract, R253: $25 \mathrm{mg} / \mathrm{L} \mathrm{SO}{ }_{2}$ with $0,3 \mathrm{ml} / \mathrm{L}$ rosemary extract, $\mathbf{R 2 5 1}: 25 \mathrm{mg} / \mathrm{L} \mathrm{SO}_{2}$ with $1 \mathrm{ml} / \mathrm{L}$ rosemary extract, $\mathbf{B b 0 1 : ~} 1 \mathrm{ml} / \mathrm{L}$ blueberry extract, $\mathbf{B b 2 5 7 :} 25 \mathrm{mg} / \mathrm{L}$ SO with $0,7 \mathrm{ml} / \mathrm{L}$ blueberry extract, Bb253: $25 \mathrm{mg} / \mathrm{L} \mathrm{SO}_{2}$ with $0,3 \mathrm{ml} / \mathrm{L}$ blueberry extract, Bb251: $25 \mathrm{mg} / \mathrm{L} \mathrm{SO}_{2}$ with $1 \mathrm{ml} / \mathrm{L}$ blueberry extract.

wines. In the first month of storage GP01, R01 and Bb251 wines showed the highest TPW value $(2.710,2.550$ and 2.520 respectively) (Table 3 ). The most remarkable differences during this evolution between the control wines were found for the grape pomace wines. The grape pomace wines showed a higher proportion of Abs280 whereas the rosemary treated wines showed a lower proportion of Abs280. As for the Abs280, no differences were found between the grape pomace and rosemary treated wines. In a study by Zamora (2003), it was shown that the absorbance values at Abs280 for young red wines ranged from 20-80 [25]. The mean values of Abs280 of the wine samples were found to be consistent with young red wines as they ranged from 54.70 to 75.20 .

Regarding to the results the rosemary experimental group wines showed a lower TWP, CI and Abs520 nm, while showing a higher hue, $\% \mathrm{Y}$ and $\mathrm{T}$ value than the TK00 control wines after 3 month of storage. These colour parameters results demonstrated that the rosemary experimental group wines lost their values more rapidly than the other experimental groups and consequently are oxidized faster after 3 month of storage. It has been studied by several authors that the reddish colour of the wine becomes orange-red during the aging and maturation of the wine [26-30]. The extract treatment during storage was determined to be significant for all parameters except dry matter, and alcohol value. After 3 months of storage in bottle TWP, WC, Abs280, Abs520, Abs620, CI, CD, \%R, $\% \mathrm{~B}$, and $\% \mathrm{dA}$ were decreased, while Abs420, \%Y, \%B, and $\operatorname{tint}(\mathrm{T})$ were increased, in agreement with aged wine results at other condition [31-33]. Glories (1984) indicate that the most appropriate $\% \mathrm{R}$ values for young red wine was found as 55.00 [34]. The \% R value of the study ranged from 53.304-61.762.

The high tone values of GP wines (in the third month storage) also indicate high $\% \mathrm{Y}$ value. The high correlation between tone value and \%Y $(r=+0.988)$ and $\% \mathrm{R}(r=$ -0.842 ) supports this result. The most $\% \mathrm{Y}$ for young red wines was found to be 35.00 [34]. The $\% \mathrm{Y}$ of the wine samples was found in range between 22.607 and 35.475. Correlations were found between $\% \mathrm{Y}$ and $\% \mathrm{dA}$ values $(r=-0.982)$ and tone values $(r=+0.988)$. The highest $\% \mathrm{Y}$ and tone values were determined in TK00 and R253 samples, respectively. \% R was found to be the lowest in the same experimental groups. Other authors have also found negative correlation between $\% \mathrm{R}$ and $\% \mathrm{dA}$ values in red wine, there was also positive correlation between the tone values [35]. Glories (1984) also indicate that the most suitable \% $\mathrm{B}$ value for red wine is 10.00 [34]. In our study we found that the $\% \mathrm{~B}$ value of the wine samples was ranged from 12.531 to 19.868 . There was no correlation between the hue values and the tone values samples, so they expressed different colour properties.

\section{Concluding remarks}

Considering this study, some of these treatments could be used as possible alternatives to $\mathrm{SO}_{2}$ during wine production. After being treatments with plant extracts occurred positive changes in chemometric properties of wines and increases were observed in terms of total wine pigments, red colour, Abs280 and Abs520 values. The result of the experimental group of different parameters with different wines treated with extracts demonstrated 
the importance of GP, Bb and R treated wines as samples with high colour properties. Rosemary extract with high yellow colour (Y\%) and tint value could be accepted as fast auto-oxidation additive after 3 months of storage. The study results demonstrated the possibility of using healthier, nonchemical additives during wine production.

This study is a part of the project titles "The Effects of Different Plant Extracts on Wine Quality Which May be an Alternative to Sulphur Dioxide" which is supported by Ege University Projects Coordination Centre of Scientific Research with project number 2017-MUH-013.

\section{References}

[1] J. Blouin, E. Peynaud, Connaisance et Travail du Vin (Dunod, Paris, 2012), p. 340

[2] H. Fulcrand, M. Dueñas, E. Salas, V. Cheynier, Am. J. Enol. Vitic. 57, 289 (2006)

[3] H. Vally, N.L.A. Misso, V. Madan, Clin. Exp. Allergy 39, 1643 (2009)

[4] S.L. Taylor, N.A. Higley, R.K. Bush, Adv. Food Res. 30, 1 (1986)

[5] OIV. OIV-MA-C1-01: R2011. Maximum acceptable limits of various substances. Compendium of international Methods of Analysis of Wines and Musts, 2 vol., In (2018 ed.), Paris, France (2011)

[6] E. Xia, X. He, H. Li, S. Wu, S. Li, G. Deng, Polyphenols Human Health Dis. 1, 47 (2013)

[7] B.H. Malayoğlu, Hayvansal Üretim 51, 59 (2010)

[8] A. García-Ruiz, C. Cueva, E.M. GonzálezRompinelli, M. Yuste, M. Torres, P.J. Martín-álvarez, M.V. Moreno-Arribas, Food Control 28, 212 (2012)

[9] K. Chen, S. Han, B. Zhang, M. Li, W. Sheng, Food Sci. Nutr. 3, 453 (2015)

[10] OIV. Compendium of International Methods of Wine and Must Analysis. International Organization of Vine and Wine (1990)

[11] OIV. Compendium of International Methods of Wine and Must Analysis. vols. 1 and 2, OIV, Paris (2005)

[12] V.L. Singleton, J.A. Rossi, Am. J. Enol. Viticulture 16, 144 (1965)

[13] R. Gil-Munoz, E. Gomez-Plaza, A. Martinez, J.M. Lopez-Roca, Food Res. Int. 30, 699 (1998)

[14] A. Kumaran, R.J. Karunakaran, Food Chem. 97, 109 (2006)
[15] Anonymous. CIE Colorimetry. 2nd ed. Publication CIE No: 152 (1986)

[16] J. Bakker, P. Bridle, S.J. Bellworthy, C. GarciaViguera, H.P. Reader, S.J. Watkins, J. Sci. Food Agric. 78, 297 (1998)

[17] V. Cheynier, M. Duenas-Paton, E. Salas, C. Maury, J.M. Souquet, P. Sarni-Manchado, H. Fulcrand, Am. J. Enol. Viticulture 57, 298 (2006)

[18] E. Peynaud, El Gusto Del Vino (Madrid, MundiPrensa, 1987)

[19] T.C. Somers, The Wine Spectrum (Adelaide, Hyde Park Press, 1998)

[20] L.S. Pilando, R.E. Wrolstad, D.A. Heatherbell, J. Food Sci. 50, 1121 (1985)

[21] M. Monagas, B. Bartolome, C. Gomez-Cordoves, Crit. Revol. Food Sci. Nutr. 45, 85 (2005)

[22] I.H. Gutierrez, E.S.P. Lorenzo, A.V. Espinosa, Food Chem. 92, 269 (2005)

[23] F. Sonni, M.J.C. Bastante, F. Chinnici, N. Natali, C. Riponi, J. Sci. Food Agric. 89, 688 (2009)

[24] A.B. Bautista-Ortin, A. Martinez-Cutillas, J.M. Ros-Garcia, J.M. Lopez-Roca, E. Gomez-Plaza, Int. J. Food Sci. Technol. 40, 867 (2005)

[25] F. Zamora, Producciony Crianza de Vinos Tintos: Fundamentos Cienticos y Practicos (Madrid, MundiPrensa, 2003)

[26] T.C. Somers, Phytochem. 10, 2175 (1971)

[27] T.C. Somers, M.E. Evans, Vitis. 25, 31 (1986)

[28] C. Romero J. Bakker, J. Agric. Food Chem. 48, 2135 (2000a)

[29] C. Romero J. Bakker, J. Food Sci. Technol. 34, 129 (2000b)

[30] V. Cheynier, M. Duenas-Paton, E. Salas, C. Maury, J.M. Souquet, P. Sarni-Manchado, H. Fulcrand, Am. J. Enol. Viticulture 57, 298 (2006)

[31] E. Boido, C. Alcalde-Eon, F. Carrau, E. Dellacassa, J.C. Rivas-Gonzalo, J. Agric. Food Chem. 54, 6692 (2006)

[32] E. García-Puente Rivas, C. Alcalde-Eon, C. SantosBuelga, J.C. Rivas-Gonzalo, M.T. Escribano Bailón, Analytica Chimica Acta 563, 215 (2006)

[33] I.H. Gutierrez, E.S.P. Lorenzoand, A.V. Espinosa, Food Chem. 92, 269 (2005)

[34] Y. Glories, Connais Vignevini 18, 195 (1984)

[35] C. Gomez-Cordoves, M.L. Gonzalez-SanJose, J. Agric. Food Chem. 43, 557 (1995) 